\title{
Information Asymmetry, Audit Quality, And Institutional Ownership On Earnings Management: Evidence From Mining Companies Listed On The Indonesia Stock Exchange
}

\author{
Metta Kusumaningtyas, Anis Chariri, Etna Nur Afri Yuyetta
}

\begin{abstract}
The intent of this research is to scrutinize the consequence of information asymmetry and audit quality on earnings management using institutional ownership as a moderating variable. The sample of this study consists of 28 mining companies listed on the Indonesia Stock Exchange (IDX) for 5 years of observation in 2012-2016, with total sample used were 140 data. Moderated Regression Analysis is used to test the hypothesis with the results that audit quality has a significant and negative influence on earnings management. While institutional ownership is accepted as a moderating variable that weakens the influence of information asymmetry on earnings management. In contrast, information asymmetry does not affect earnings management and institutional ownership does not strengthen the influence of audit quality on earnings management.
\end{abstract}

Keywords: Earnings Management, Information Asymmetry, Audit Quality, Institutional Ownership, Mining Companies, Indonesia

\section{INTRODUCTION}

Earnings management is very attractive to corporate stakeholders, especially once earnings are often regarded as accurate forecasters of financial reporting quality, because accounting accruals are enlightening nearby financial reporting quality. Nonetheless, accruals could also function as financial reporting quality ascertains that cannot be relied upon because of the possibility of bias and manipulation (1).

Some research results state that so far company managers carry out earnings management and their actions can be stated as manager' approaches to beautifying financial statements that will be submitted to stakeholders. For instance, (2) determined that audit quality has a significant negative relationship with earnings management, while (3) and (4) argue that audit functions assist in information asymmetry and conflicts of interest that follow between shareholders and managers. As suggested by agency theory, monitoring instruments are supposed to harmonize the

Revised Manuscript Received on April 19, 2019.

Metta Kusumaningtyas, (a) Doctoral Program in Economics, Business and Economics Faculty, University of Diponegoro, Jl. Erlangga Tengah No.17, Semarang, 50241, Central Java, Indonesia; (b) Accounting Department, Business School of Bank BPD Jateng (STIE Bank BPD Jateng), Jl. Pemuda No. 4A, Semarang, 50139, Central Java, Indonesia. (email: metta.kusumaningtyas@gmail.com)

Anis Chariri, Accounting Department, Business and Economics Faculty, University of Diponegoro, Jl. Prof. Sudharto, Kampus Undip Tembalang, Semarang, 50275, Central Java, Indonesia,

(email: anis_chariri@live.undip.ac)

Etna Nur Afri Yuyetta, Accounting Department, Business and Economics Faculty, University of Diponegoro, Jl. Prof. Sudharto, Kampus Undip Tembalang, Semarang, 50275, Central Java, Indonesia.

(email: etnanurafri@yahoo.com) interests of shareholders and managers and reduce conflicts of interest and subsequent opportunistic behaviors (1).

From this, indirect information asymmetry is an alternative indicator of how so far investors have received incorrect information in company's financial statements obtained from financial markets (5). Previously, the result of research conducted by (6) stated that agency problems motivate the conduct of earnings management and information asymmetry. This earnings manipulation behavior also arises because of the high information asymmetry between the management and other parties who do not have enough resources or access information that is used to monitor management actions (7).

Several large companies such as Enron, Merck, World Com, and majority of other companies registered in the United States are examples of a number of cases of earnings management that have been widely known in terms of reporting financial statements by manipulating the accounting record system (8).

In Indonesia, several cases have arisen in relation to earnings management that afflict Bumi Resources (BUMI) Ltd. company, where BUMI Ltd. was reported by Indonesia Corruption Watch (ICW) for alleged manipulation of the sale of three Bakrie Group coal mining companies to the Director General of Taxes. The coordinator of ICW's Budget monitoring and analysis division, suspected that financial reporting engineering carried out by BUMI Ltd., and its subsidiaries since 2003-2008, caused state losses of US \$ 620.49 million. In addition to these cases, allegations of manipulation of sales reports occurred at Kaltim Prima Coal (KPC) Ltd Company, Arutmin Indonesia Ltd Company, and the parent of the two companies, namely BUMI Ltd. The results of calculations carried out by ICW using various primary data including audited financial statements, show that the sales report of BUMI Ltd. during 2003-2008 was US \$ 1.06 billion lower than it actually was. As a result, during that time, it was also estimated that the losses suffered by the state from the lack of revenue from the production of Coal (royalty) amounted to US \$ 143.18 million (www.tempo.co.id).

The case of earnings management that happened to other mining companies was a case that occurred in Ancora

Published By: 
Mining Service (AMS) Ltd Company, in 2011 it was reported by the Justice Care Community Forum to the Directorate General of Tax of the Ministry of Finance for alleged financial report manipulation. The Chairman of that forum Investigation Section, Mustopo, explained that the indications of manipulation were seen from the income of IDR 34.9 billion but there was no investment movement. In addition, evidence of interest payments of IDR 18 billion was found, even though AMS claimed to have no debt. The forum also found evidence of receivables valued at IDR 5.3 billion but there was no clear transaction (www.republika.co.id).

Another case is still from a mining company, Timah Ltd company. The Timah Employee Association considers that directors have done a lot of public lies through the media. An example is in the press release of the 2015 on financial report which said that efficiency and strategy have produced positive performance. In fact, in semester 1 (one) operating profit lost IDR 59 billion (http://economy.okezone.com).

Information asymmetry occurs because agents tend to have more information about the company than principals. Furthermore, the presence of information asymmetry will lead to various opportunistic actions that will only benefit the manager, the most common behavior of which is earnings management even to the point of manipulating the company's financial statements (9).

Agency theory problems relate with ownership and control, along with-information asymmetry in a company, and also involve information from the financial statement that occurs between principal and agent, which builds the need for an external audit (2). However, despite the demand for external audits, external audit quality must be subject to various guidelines and procedures, such as audit standard commitments, independence, competence, and professional care training. If these things are not implemented by an external auditor, the auditor's role will not function, because external auditors have an important role in making verification of financial statements produced by a company that is stated fairly in accordance with the standards of accounting. Therefore, financial reporting produced by the company also presents a fairness of economic conditions and the operational findings of the entity (10).

With the occurrence of various financial cases that occur, it will raise the question of whether the external audit is considered to be effective in limiting the earnings management carried out by company managers which has caused a wave of audit failures in the capital market (11). External audit is an important instrument for shareholders to ensure transparency and credibility of financial reporting produced by a company. Audit services may not directly ensure that there is earnings manipulation carried out by the company manager, and also ensures detection of forged data has been detected. However, the number of manipulations found depends on the quality of the audit service. In addition, auditor experience, auditor knowledge about the industry, and auditor independence greatly affect the quality of audit services. The knowledge and experience owned by the auditor will greatly assist the auditor to diagnose complex problems in certain company industries (10).
Earnings management carried out by company managers is a serious concern from the auditor because it can give an unnatural presentation. In addition, it will make auditors more worried if company managers use accounting standards that are questionable in accounting practices in a company (12). Broader accounting quality literature, according to (13) has identified the importance of the role of external auditors in relation to the practice of earnings management as a potential practice that can reduce these practices. However, auditors often try to fulfill clients' desires to be satisfied on the one hand and to avoid litigation and regulatory consequences on the other, and are concerned about possible damage to reputation. Research results (14) state that the auditor deals with two important objectives; satisfies the client and avoids the risk of third parties. Based on agency theory by (15) higher audit quality can detain the insiders from misuse of accounting based on contracts and earnings manipulation as the result on ownership and control. Audit quality plays an essential role in decreasing earnings management while auditors accomplish an authorization duty regarding financial statement integrity (1).

Institutional ownership has an ability to control management in a company through an effective supervision process so as to decrease earnings management. The percentage of certain shares owned by the institution can affect the process of preparing financial statements that do not cover the possibility of accrual in accordance with the interests of the management (16). Furthermore (17), (18), and (8) found evidence that the supervisory actions taken by a company and institutional investors could limit the behavior of managers. Thus, corporate supervisory actions carried out by institutional ownership can encourage managers to focus to their attention on company performance and then it will limit manager behavior in earnings management.

According to (19), also recognized a significant and positive relationship between the concentration of institutional ownership and earnings management. Hereafter (20), (21), and (22) obtained that ownership concentration causes information asymmetry between managers and investors which motivates the managers to practice earnings management. Based on (23) agreed that institutional ownership had a positive effect on earnings management, while (24) found that institutional ownership had no effect on earnings management.

Leverage is one variable that also affects earnings management. Leverage is the ratio of debt to assets. The higher the debt to asset ratio (leverage) of a company, which is equivalent to the closer the company has to the constraints in the debt agreement and the greater the probability of breach of agreement, the more managers are motivated to use accounting methods that increase income (25). Several studies have shown that leverage affects earnings management; for instance (26) concluded that leverage has a significant effect on earnings management. In the study of (27) and (28) leverage is proven to be one mechanism that reduces management's opportunistic behavior. Research by (29) states that 
leverage as a control variable has a 
significant negative relationship with discretionary accruals.

Other variables that influence earnings management are company growth, company age, and company size. According to (30) high growth companies in America will tend to take earnings management actions because they have strong financial needs, while also showing that companies with a younger operational age tend to violate GAAP rules more than companies with older operational age. However, research in China shows that older companies tend to receive modified audit opinions from their auditors, because older Chinese firms tend to be financially unstable (31). Based on (32), it was concluded that leverage, company growth, and company age as a control variables and had a positive and significant effect on earnings management.

Large companies usually have the role of wider stakeholders. This indicates that various policies of large companies will have a large impact on the public interest compared to small companies. Large companies are more concerned by the community so that they are more careful in conducting financial reporting, so that the impact of the company must report its condition more accurately (33). In line with (34), it was found that the size of companies in the United States negatively affected earnings management. Larger companies lack the drive for earnings management compared to small companies. Whereas research in Indonesia by (35) found that company size measured by using the natural logarithm of the company's equity market value at the end of the year had a significant negative effect on the degree of earnings management, indicating a larger extent of earnings management. This is different from the research of (36) which states that firm size does not have a significant effect on earnings management.

This study uses a sample of mining companies listed on the Indonesia Stock Exchange (IDX), because the mining industry is one of the pillars of economic activity in Indonesia. Mining companies play an important role in the economy because Indonesia is a country that produces potential natural and mineral resources. In addition, the nature and characteristics of the mining industry differ from those of other industries. Among other things, mining companies require very large, long-term investment costs; have high risks and uncertainties, thus making the funding problem a major issue related to the development of the company.

This study aims to explore the effect of information asymmetry and audit quality on earnings management with institutional ownership as a moderating variable. Research on earnings management with the object of mining companies is still little done in Indonesia. This study contributes to adding to the literature the results of existing research using the information asymmetry and audit quality as independent variables and institutional ownership as moderating variables. In addition, this study also used control variables consisting of leverage, sales growth, firm age, and firm size.

The results of this study are presented in the following order. Section 2 presents the literature review. Section 3 describes the methodology/materials which consists of research design also data and the sample criteria used. In addition, this section also describes research variables measurement and specifications of the empirical model used for hypotheses testing. Section 4 describes the empirical results of the study and findings. Finally, section 5 presents conclusions.

\section{LITERATURE REVIEW}

\section{A. Agency Theory}

Agency theory describes the relationship between two parties, namely the owner (principal) and manager (agent). The owner is defined as the party who gives the mandate to another party called the manager, to be able to act on behalf of the owner. Based on the results of the study of (9) there are two types of agency relations, namely that between managers and shareholders and that between managers and bondholders. Furthermore (9) states that agency relations are a contract between the owner and manager.

Agency issues arise because of a conflict of interest between shareholders and managers, because the maximum utility is not met. Company managers know more about internal information and company prospects in the future than owners. So, there is a high probability that managers don't always act in the best interests of the owner (9).

\section{B. Information Asymmetry and Earning Management}

In consonance with (37) unbalanced information in agency theory is also known information asymmetry. This information asymmetry arises as a result of the unequal distribution of information between owners and managers. Ideally, the owner gets the information needed to measure the level of results obtained from the manager's business But in reality, the success measures consumed by the owner cannot explain the relationship between the success that has been achieved, and the efforts that have been made by the agent.

Information asymmetry is a condition where managers have access to information on the company's prospects that are not owned by parties outside the company. In situations where shareholders have less information than managers, managers can use the flexibility they have to practice earnings management.

In tandem with (38) agents are in a position that has a large capacity of the information of the self, the activity environment and the firm as a whole than the principal Assuming that individuals act on maximizing self-interest, then the information asymmetry possessed by managers will drive agents to hide some information from the principal. So often in conditions like this, the principal is in an unfavorable position.

According to (7) empirical evidence which states that information asymmetry measured using spread bid-ask and dispersion analyst estimates have a positive effect on earnings management.

H1. Information asymmetry has a positive effect on earnings management. 


\section{Audit Quality and Earnings Management}

Audit is a systematic process that ensures that the information presented in the financial statements regarding the company's operational activities is truly objective, reliable, and trustworthy.

The audit quality is the center of external supervision and is one of the factors considered for earnings management. The high quality of audit services will add credibility to the quality of the contract process. If a company holds a contract that applies to accounting numbers between managers and investors, it can reduce agency problems (37).

Based on (27) and (37) stated that the relevance of the auditor's report in examining contractual relations and reporting contract violations was influenced by audit quality. While (28) and (2) expressed the opinion that qualified auditors have greater tendency to detect earnings management practices.

According to (39) there is evidence that the size of earnings management was significantly lower among companies audited by Big 4 audit firms compared with companies that audited by Non Big 4 audit firms. Largesized professional auditors have more technical ability to find violations in their clients' accounting systems compared to small-sized auditors (40).

Research conducted by (41), (42), and (43) suggest that high- quality auditors prefer to report errors and irregularities and are less willing to accept questionable accounting practices.

H2. Audit quality has a negative effect on earnings management.

D. Institutional Ownership, Information Asymmetry, and Earnings Management

The agency theory recognizes the existence of contradictions between outside and internal investors of a company (manager, controlling shareholder). The study found that firms in developing countries are primarily subject to the principal agency problem that arises from the conflict among the controlling shareholders and minority shareholders, by (44), (45), and (46).

Institutional ownership has the capability to monitor management through an effective controlling process so as to decrease earnings management. The percentage of certain shares owned by the institution can affect the process on preparing financial statements that do not cover the possibility of accrual in accordance with the interests of the management (16).

In concert with (8), found evidence that the supervisory actions taken by a company and institutional ownership could limit the behavior of managers. Corporate supervisory actions by institutional ownership could push managers to focus their attention more on the firm's performance so that it will decrease opportunistic or selfish behavior. This is in line with (35) who also found that the presence of high institutional ownership limits managers engagement in earnings management.

H3. Institutional ownership weakens the influence of information asymmetry on earnings management.
E. Institutional Ownership, Audit Quality, and Earnings Management

Institutional ownership is the ownership of company shares by an outside party in the form of an institution, which is expected to reduce deviant earnings management actions. With high managerial ownership, investors will get a smaller chance of overseeing the company.

Research conducted by (47) found that high institutional ownership limits managers engagement in earnings management. Audit conducted by Big 4 audit firms were associated with higher expertise and reputation compared to audits conducted by Non Big 4 audit firms. Therefore, Big 4 audit firm auditors will strive to seriously maintain their market shares, public trust, and reputation by providing protection to the public.

H4. Institutional ownership strengthens the influence of audit quality on earnings management.

\section{METHODOLOGY/MATERIALS}

\section{A. Research Design}

This research is an empirical study conducted by testing hypotheses to obtain empirical evidence regarding the effect of information asymmetry and audit quality on earnings management with institutional ownership as a moderating variable. To test the hypothesis in this study, the research approach used is a quantitative approach.

\section{B. Data and Sample}

The study data set consisted of all mining companies listed on the Indonesia Stock Exchange (IDX) during the period 2012-2016. This study uses the mining company sector as an object of research because the mining sector is an industry that is able to provide a relatively high contribution margin for investors, taking into consideration the financial statements produced by companies in this sector and the issues that are commonly considered by investors (48).

The sample used in the study has several predetermined criteria. First, this study uses mining companies that were consistently listed on the Indonesia Stock Exchange (IDX) from January 1, 2012 until December 31, 2016. Secondly, the companies published financial statements for the 20122016 periods, and the reports are available at the Indonesian Capital Market Directory, www. idx.co.id or company website. Thirdly, data on research variables are completely available in the company.

Based on the criteria above, then in this study identified 28 companies with 5 years of sample observations, the research sample used in this study comprised of 140 samples in the year of observation. The companies used in the sample of this study have been categorized in the mining company sub-sector and can be seen in table 1 as follows. Table 1 below explains the contribution of each sub-sector in the mining company used in this study. In table 1 it can be seen that the largest contribution was given by the coal company sub-sector (50\%) while the smallest contribution 
International conference on Recents Advancements in Engineering and Technology (ICRAET-18) |15th and 16th March 2019|Siddhartha Institute of Technology \& Sciences, Telangana, India.

was given by the rock company sub-sector $(8 \%)$.

Table 1. Research data samples company per sector

\begin{tabular}{|c|l|c|c|}
\hline No & \multicolumn{1}{|c|}{ Sub-Sector } & $\begin{array}{c}\text { Total } \\
\text { Company }\end{array}$ & Percentage \\
\hline 1 & Coal & 14 & $50 \%$ \\
\hline 2 & Metals and other minerals & 6 & $21 \%$ \\
\hline 3 & Oil and gas & 6 & $21 \%$ \\
\hline 4 & Rock Total & 2 & $8 \%$ \\
\hline & \multicolumn{2}{|c|}{28} & $100 \%$ \\
\hline \multicolumn{2}{|c|}{} \\
\hline
\end{tabular}

\section{Variable Measurement}

\section{Dependent Variable}

In this study, the dependent variable used is earnings management proxied by discretionary accruals. Total accruals can be separated into discretionary accruals and non-discretionary accruals. Discretionary accruals can be manipulated by management using professional judgment in accounting choices. The research literature states that discretionary accrual models are often used in detecting earnings management (49).

Discretionary accruals have been used by many previous researchers for the measurement of earnings management (50), (51), (52), (53), and (49). There are several models applied calculating discretionary accruals. However, the modified Jones model has been used extensively in previous research to measure earnings management. Next, (54), (55), (28), and (56), with Jones model modified as a measure for earnings management. This model is used because it is considered to be the best model for detecting earnings management (57). To get the value of the discretionary accrual a calculation is done based on the following steps:

a. Calculate total accrual with the equation:

Total Accrual $($ TAC $)=$ net income-cash flow from operating

b.Calculates accrual values with multiple linear regression equations based on ordinary least square (OLS) as follows: $\mathrm{TAC}_{\mathrm{t}} / \mathrm{A}_{\mathrm{t}-1}=\alpha_{1}\left(1 / \mathrm{A}_{\mathrm{t}-1}\right)+\alpha_{2}\left(\Delta \mathrm{REV}_{\mathrm{t}} / \mathrm{A}_{\mathrm{t}-1}\right)+\alpha_{3}\left(\mathrm{PPE}_{\mathrm{t}} / \mathrm{A}_{\mathrm{t}-1}\right)+\mathrm{e}$ (2)

Notes:

$\mathrm{TAC}_{t}$ : The total accrual of company $\mathrm{i}$ in period $\mathrm{t}$

$A_{t-1}$ : Total assets for the sample of company $i$ in year $t-1$

$\triangle \mathrm{REV}_{\mathrm{t}}$ : Changes in company sales i from year $\mathrm{t}-1$ to year $\mathrm{t}$

$\mathrm{PPE}_{\mathrm{t}}$ : Property, plant and equipment of the yeart

c. By using the re gression coefficient above, then calculating the value of non-discretionary accrual (NDA) can be calculated by the formula:

$\mathrm{NDA}_{\mathrm{t}}=\alpha_{1}\left(1 / \mathrm{A}_{\mathrm{t}-1}\right)+\alpha_{2}\left(\left(\Delta \mathrm{REV}_{\mathrm{t}}-\Delta \mathrm{REC}_{\mathrm{t}}\right) / \mathrm{A}_{\mathrm{t}-1}\right)+$ $\alpha_{3}$ (PPEt/At-1)
Notes :

$\mathrm{NDA}_{t}$ : Non-discretionary accruals in year $\mathrm{t}$

$\triangle \mathrm{REC}_{\mathrm{t}}$ : Changes in corporate receivables i fromyear $\mathrm{t}-1$ to yeart

$\alpha \quad$ : Fitted coefficients obtained from the regression results on calculations

d.Calculates the value of the discretionary accrual (DAC) with the equation : $\mathrm{DAC}_{t}=\left(\mathrm{TAC}_{\mathrm{t}} / \mathrm{A}_{\mathrm{t}-1}\right)-\mathrm{NDA}_{\mathrm{t}}$

Notes :

$\mathrm{DAC}_{\mathrm{t}}$ : Discretionary accrual in company iin period $\mathrm{t}$

\section{Independent Variable \\ a. Information Asymmetry}

Information asymmetry is measured using a relative bidask spread. In this case information asymmetry is measured by looking at the price difference when asking the price at the company's stock bid or the difference between the selling price and the buying price of the company's stock (58).

\section{b. $\quad$ Audit Quality}

Audit quality in this study was measured using dummy variables. If the company is audited by audit firms affiliated with the Big 4, then a score $=1$ is given, but if the company is audited by an audit firm that is not affiliated with the Big 4 , then a score $=0$ is given.

\section{3. $\quad$ Moderating Variable}

This study uses institutional ownership variables as moderating variables. Institutional ownership is the total of company shares owned by institutional shareholders. In this study, institutional ownership is measured by the proportion of shares held divided by the number of shares issued by the company.

\section{Control Variable \\ a. Leverage}

Financial leverage (leverage ratio) is a comparison between funds used to finance a company or funds obtained from external companies with funds provided by the company owner. Leverage is formulated with long-term debt plus current debt divided by total assets/ratio leverage (10).

\section{b. $\quad$ Sales Growth}

The firm's growth measures how well the firm maintains its economic position, both in its industry and in overall economic activity (59). The firm's growth shows the company's ability to survive in competitive conditions. The firm's growth is measured by the sales growth of the company's operational activities for one year (32). Sales growth is calculated from total sales in year $\mathrm{t}$ minus total sales in year $\mathrm{t}-1$ divided by total sales in year $\mathrm{t}$.

\section{c. Firm Age}

Firm age shows how long the company has stood. In this research the age of the company can be measured based on the number of years since the company was founded (32).

d. Firm Size 
Firm size is the size of firm assets. Firm size is proxied by the natural logarithm of total assets (10).

\section{Specifications of Research Models Used}

In accordance with the theoretical framework and the submission of hypotheses in this research, the following regression model was developed to investigate the hypothesis. The regression model is as follows: 


\section{$\mathrm{DAC}=\alpha_{0}+\alpha_{1} \mathrm{ASIM}+\alpha_{2} \mathrm{AUD}+\alpha_{3} \mathrm{INV}+\alpha_{4} \mathrm{ASIM} * \mathrm{INV}+$ $\alpha_{5}$ AUD $*$ INV $+\alpha_{6}$ LEV $+\alpha_{7}$ SALESGROW TH + $\alpha_{8} \mathrm{AGE}+\alpha_{9} \mathrm{LNSIZE}+\mathrm{e}$}

(5)

The full operational definition of variable measurement is presented in table 2 below.

Table 2. Variable measurement and operational definition

\begin{tabular}{|c|c|c|}
\hline Symbol & Variable & Operational definition \\
\hline \multicolumn{3}{|l|}{ Dependent variable } \\
\hline DAC & $\begin{array}{c}\text { Eamings } \\
\text { Management }\end{array}$ & $\begin{array}{l}\text { Discretionary accrual (Modified } \\
\text { Jones) }\end{array}$ \\
\hline \multicolumn{3}{|c|}{ Independent variable } \\
\hline ASIM & $\begin{array}{l}\text { Information } \\
\text { Asymmetry }\end{array}$ & Relative bid-ask spread \\
\hline AUD & Audit Quality & $\begin{array}{l}\text { If the company is audited by audit } \\
\text { firm affiliated with Big } 4 \text {, then a } \\
\text { score }=1 \text { is given, but if the } \\
\text { company is audited by audit firm } \\
\text { that is not affiliated with Big } 4 \text {, } \\
\text { then a score }=0 \text { is given }\end{array}$ \\
\hline \multicolumn{3}{|c|}{ Moderating variable } \\
\hline INV & $\begin{array}{l}\text { Institutional } \\
\text { Ownership }\end{array}$ & $\begin{array}{l}\text { The proportion of shares held } \\
\text { divided by the number of shares } \\
\text { issued by the company }\end{array}$ \\
\hline \multicolumn{3}{|l|}{ Control variable } \\
\hline LEV & Leverage & $\begin{array}{l}\text { Total (Long-tem debtplus current } \\
\text { debt) } \\
\text { divided by total assets }\end{array}$ \\
\hline SALESGROWTH & Sales Growth & $\begin{array}{c}\text { Total sales in year } \mathrm{t} \text { minus total } \\
\text { sales in year } \mathrm{t}-1 \text { divided by total } \\
\text { sales in year } \mathrm{t}\end{array}$ \\
\hline AGE & Firm Age & $\begin{array}{l}\text { The total of years since the } \\
\text { company was founded }\end{array}$ \\
\hline LNSIZE & Firm Size & $\begin{array}{l}\text { The natural logarithm on total } \\
\text { assets }\end{array}$ \\
\hline
\end{tabular}

The use of independent variables and control variables is also based on previous research conducted by $(60),(6)$, and (61). Control variables used in this research to control the characteristics of companies that can affect the level of earnings management (10).

\section{RESULTS AND FINDINGS}

\section{A. Descriptive Statistics Analysis}

This part describes descriptive statistics for all observations containing the value of minimum, maximum, mean, and standard deviation. Descriptive statistics analysis results are presented in table 3 below.

Table 3. Descriptive statistics

\begin{tabular}{|c|r|r|r|r|}
\hline Variable & Minimum & Maximum & Mean & $\begin{array}{c}\text { Standard } \\
\text { Deviation }\end{array}$ \\
\hline DAC & -108.4695 & 0.4681 & -0.9657 & 9.1584 \\
ASIM & 0 & 75 & 13.14 & 18.690 \\
AUD & 0 & 1 & 0.5400 & 0.5000 \\
INV & 0.0000 & 0.7953 & 0.2240 & 0.2533 \\
ASIM*INV & 0.0000 & 19.6450 & 2.3035 & 4.2975 \\
AUD*INV & 0.0000 & 0.7244 & 0.1043 & 0.2059 \\
LEV & 0.0058 & 3.0000 & 0.5227 & 0.3372 \\
SALES & & & & \\
GROWTH & -23.5713 & 0.9950 & -0.2750 & 2.2807 \\
AGE & 7 & 65 & 30.68 & 14.022 \\
LNSIZE & 1.0117 & 7.9786 & 6.6179 & 0.9055 \\
\hline
\end{tabular}

Earnings management (DAC) shows a minimum value of -108.4695 which shows that $-10,846.95 \%$ of total assets in year $\mathrm{t}-1$ is the lowest discretionary accrual. The maximum value of 0.4681 shows that $46.81 \%$ of the total assets of year $\mathrm{t}-1$ is the highest discretionary accrual. The mean value is -0.9657 and the standard deviation value is 9.1584 .

Information asymmetry (ASIM) produces a minimum value of 0 which indicates the difference between the selling price and the lowest stock purchase price is IDR 0 . The maximum value is IDR 75 which indicates that the highest selling price and purchase price is IDR 75 . The mean value is 13.14 and the standard deviation is 18.690 .

Audit quality (AUD) shows a minimum value of 0 , indicating that 64 company samples $(45.7 \%)$ were audited by audit firms that were not affiliated with the Big 4 . The maximum value was 1 , indicating that there were 76 company samples $(54.3 \%)$ audited by audit firms affiliated with Big 4. Mean value is 0.54 and standard deviation is 0.5000 .

Institutional ownership (INV) shows a minimum value of 0.0000 , which indicates that the lowest number of shares held by an institution is $0 \%$. The maximum value is 0.7953 , indicating that the highest number of shares owned by the institution is $79.53 \%$. The mean value is 0.2240 with a standard deviation value of 0.2553 .

Institutional ownership as the moderating variable (ASIM*INV) between information asymmetry and earnings management shows a minimum value of 0.000 and a maximum value of 19.6450 . The mean value is 2.3035 with a standard deviation value of 4.2975 .

Institutional ownership as a moderating variable (AUD*INV) between the relationship between audit quality and earnings management shows a minimum value of 0,000 and a maximum value of 0.7244 . The mean value is 0.1043 with a standard deviation value of 0.2059 .

Leverage (LEV) shows the minimum value of 0.0058 , which shows the lowest leverage value which means that $0.58 \%$ of the total assets of the company is from debt. The maximum value is 3 , indicating that $300 \%$ of the company's total assets are from debt. The mean value is 0.5227 and the standard deviation value is 0.3372 .

The company's growth (SALESGROWTH) shows a minimum value of SALESGROWTH -23.5713, which shows that $-235.713 \%$ of total sales in year $t-1$ is the lowest total sales. The maximum value is 0.9950 , indicating that $99.50 \%$ of total sales in year $\mathrm{t}-1$ is the highest total sales. The mean value is -0.2750 with a standard deviation value of 2.2807 .

The firm age (AGE) has a minimum value of 7 , which indicates that the lowest age of the company is 7 years. The maximum value of 65 indicates that the highest age of the company is 65 years. The mean value is 30.68 and the standard deviation value is 14.022.

Firm size (LNSIZE) has a minimum value of 1.0117 and a maximum value of 7.9786 . The mean value of 27.25 , shows that the average value of the company's assets is 6.6179 and the standard deviation value is 0.9055 .

\section{B. Correlation Matrix Test Results}

As shown in table $4 \mathrm{a}$ and $4 \mathrm{~b}$, earnings management (DAC) is not correlated with all factors of independent variables but shows a positive correlation with one firm size control variable (LNSIZE) and significant at $5 \%$ level 
(0.527). Based on table $4 \mathrm{a}$ and $4 \mathrm{~b}$, it can also be seen that there are several moderating variables that are positively and significantly correlated and have a negative and significant correlation with independent variables and control variables. The correlation is not strong (lower than 0.80 ) because all of these variables are included in the same model. According to (62) 0.80 is recommended as a threshold at which multicollinearity concerns can threaten regression analysis and indicate that a VIF value of less than 10 is acceptable.

Table 4a. Correlation Coefficient

\begin{tabular}{|c|c|c|c|c|c|c|}
\hline & DAC & ASIM & AUD & INV & $\begin{array}{l}\text { ASIM }^{*} \\
\text { INV }\end{array}$ & $\begin{array}{l}\text { AUD* } \\
\text { INV }\end{array}$ \\
\hline DAC & 1.000 & & & & & \\
\hline ASIM & 0.053 & 1.000 & & & & \\
\hline AUD & 0.098 & 0.105 & 1.000 & & & \\
\hline INV & 0.073 & -0.136 & -0.137 & 1.000 & & \\
\hline ASDM* & & & & & & \\
\hline $\begin{array}{l}\text { INV } \\
\text { AUD* }\end{array}$ & 0.046 & $0.398^{88}$ & $-0.173^{*}$ & $-0,549 * 8$ & 1.000 & \\
\hline INV & 0.048 & -0.128 & $0.467 * 8$ & $0.572^{88}$ & $0.174^{*}$ & 1.000 \\
\hline LEV & -0.061 & -0.127 & -0.097 & -0.033 & -0.156 & -0.076 \\
\hline SALES & & & & & & \\
\hline GROWTH & -0.015 & -0.001 & 0.147 & $-0.236^{* 8}$ & $-0.235^{* 8}$ & 0.048 \\
\hline AGE & 0.133 & $-0.245^{* 8}$ & $0.208^{*}$ & -0.142 & $-0.259^{* 8}$ & -0.129 \\
\hline LNSIZE & $0.527 * 8$ & $0.0190^{*}$ & $-0.474^{* 8}$ & $-0.226^{* 8}$ & 0.009 & 0.059 \\
\hline
\end{tabular}

Table 4b. Correlation Coefficient

\begin{tabular}{|c|c|c|c|c|}
\hline & \multicolumn{3}{|c|}{ SALES } & $\begin{array}{c}\text { LN } \\
\text { SIZE }\end{array}$ \\
\hline DAC & & 年 & 然 & \\
\hline ASIM & & & & \\
\hline AUD & & & & \\
\hline INV & & & & \\
\hline ASIM* & & & & \\
\hline INV & & & & \\
\hline AUD $^{*}$ & & & & \\
\hline INV & & & & \\
\hline LEV & 1.000 & & & \\
\hline SALES & & & & \\
\hline GROWTH & 0.032 & 1.000 & & \\
\hline AGE & -0.094 & 0.045 & 1.000 & \\
\hline LNSIZE & -0.061 & 0.063 & 0.064 & 1.000 \\
\hline
\end{tabular}

\section{Hypothesis Testing Results}

Table 5 below presents the results of multiple regression on testing hypotheses in this study. Hypothesis 1, which states that information asymmetry (ASIM) has a positive effect on earnings management, is declared not acceptable, as shown in table 5 , the results of hypothesis testing show non-significant results that is equal to 0.216 .

Hypothesis 2 which states that audit quality (AUD) has a negative effect on earnings management, otherwise accepted, as shown in table 5, the results of hypothesis testing show a significant result of 0.013 .

Hypothesis 3 which states that institutional ownership strengthens the influence of information asymmetry on earnings management (ASIM*INV), otherwise accepted, as shown in table 5 , the results of hypothesis testing show a significant result of 0.064 .

Hypothesis 4 states that institutional ownership strengthens the influence of audit quality on earnings management (AUD*INV), otherwise not accepted, as shown in table 5, the results of hypothesis testing show significant results that is equal to 0.914 .

From table 5 it can also be seen that the control variables that have a significant effect on earnings management are the age of the company (AGE) and the size of the company (LNSIZE). Leverage control variables (LEV) and sales growth (SALEGROWTH) have no effect on earnings management. Based on table 5 , the calculated $F$ value is 9.210 with a significant level of 0.000 , indicating that all independent variables simultaneously and significantly affect the dependent variable.

Table 5. Regression Test

\begin{tabular}{|c|c|c|c|c|}
\hline & B & $\mathbf{t}$ & Sig. & \\
\hline (Constant) & -50.579 & -8.844 & 0.000 & \\
\hline ASIM & 0.054 & 1.242 & 0.216 & \\
\hline AUD & -5.156 & -2.505 & 0.013 & $* *$ \\
\hline INV & 12.090 & 2.635 & 0.009 & 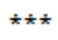 \\
\hline ASIM*INV & -0.423 & -1.869 & 0.064 & $*$ \\
\hline AUD*INV & 0.597 & 0.108 & 0.914 & \\
\hline LEV & -0.946 & -0.491 & 0.624 & \\
\hline SALESGROWTH & 0.032 & 0.109 & 0.914 & \\
\hline $\mathrm{AGE}$ & 0.109 & 2.112 & 0.037 & $* *$ \\
\hline LNSIZE & 7.110 & 8.571 & 0.000 & $*$ \\
\hline \multicolumn{5}{|l|}{ Adj R $234.7 \%$} \\
\hline Significant: ${ }^{*} \mathrm{p}<0$. & $\mathrm{p}<0.05$ & $<0.01$ & & \\
\hline
\end{tabular}

The coefficient of determination is indicated by the value of adjusted R2 can be seen in table 5, showing that the coefficient of determination shows the value of adjusted R2 is $34.7 \%$. This means $34.7 \%$ variation in earnings management (DAC) can be explained by variations of the independent variables namely information asymmetry (ASIM), audit quality (AUD) and moderating variables namely, institutional ownership (INV), and leverage control variables (LEV), company growth (SALESGROWTH), company age (AGE), and company size (LNSIZE). The remaining $65.3 \%$ is explained by other causes outside the model.

\section{Discussion}

This study examines the effect of information asymmetry and audit quality on earnings management with institutional ownership as a moderating variable. The study consists of four hypotheses and has been tested with the results of hypothesis 1 which states that information asymmetry has a positive effect on earnings management while the results of the hypothesis are not accepted. Information asymmetry is stated to have no effect on earnings management. These findings indicate that there is a possibility of errors in previous financial reporting that are not in accordance with qualitative rules (63). Another reason is the possibility of a relatively small number of samples so that the parameter estimation is less precise eliminating the effects of information asymmetry ton earnings management (35). The results of this study are consistent with research by (64), (65), and (66). However, the results of the study are not in accordance with the research conducted by (67), (68), (69), (70), and (71).

Hypothesis 2 states that audit quality has a negative effect on earnings management, showing the results of the hypothesis are accepted. The results of hypothesis testing stated that audit quality has a negative effect on earnings management. From the results of research data shows that if a company audited by audit firm affiliated with Big 4 shows the results of a report that is more qualified and can prevent the practice of earnings management by a manager within a company. Auditors 
International conference on Recents Advancements in Engineering and Technology (ICRAET-18) |15th and 16th March 2019|Siddhartha Institute of Technology \& Sciences, Telangana, India.

who are affiliated with Big 4 are more 
competent and professional so that they have broader and more adequate knowledge about how to detect earnings management. Furthermore, the results of this study are in line with the results of research conducted by (72), (73), (74), (75), and (1). However, the results of this study do not support the results of research conducted by (35),(65), and (10).

Hypothesis 3 states that institutional ownership weakens the influence of information asymmetry on earnings management. As stated by (16) that institutional ownership has the ability to control management through an effective monitoring process so as to reduce earnings management. The percentage of certain shares owned by the institution can affect the process of preparing financial statements that do not cover the possibility of accrual in accordance with results of this study contradict the results of the study (69) and (71).

Hypothesis 4 states that institutional ownership strengthens the influence of audit quality on earnings ownership is not a factor that can improve audit quality. Audit conducted by Big 4 audit firm has high expertise and reputation compared to audits conducted by Non Big 4 audit firm. Therefore, Big 4 auditors will strive to seriously maintain market share, public trust, and reputation by providing protection to the public. The results of this study research conducted by (72).

\section{CONCLUSION}

The purpose of this study was to examine the effect of information asymmetry and audit quality on earnings management with institutional ownership as a moderating variable. The sample used in this study comprised of mining companies listed on the Indonesia Stock Exchange in 20122016. Based on the predetermined sample criteria, the resulting sample was 140 company samples. four hypotheses, the accepted hypothesis is the second hypothesis which states that the audit quality has a negative effect on earnings management and a third hypothesis which states that institutional ownership weakens the influence of information asymmetry on earnings management. The first hypothesis which states that information asymmetry influences earnings management and the fourth hypothesis which states that institutional ownership strengthens the influence of audit quality on earnings management is not supported.

The results of the study thus states that information asymmetry cannot be used as an indicator in suppressing earnings management in a company. However, good audit quality will prevent earnings management practices in a company so that auditors can play a more important role in inhibiting earnings management practices that occur in a company. This can result in support for the argument that the auditor is effective in reducing managerial opportunistic activities. Thus, research supports agency theory predictions the interests of the management. The results of this study support research conducted by (8), (35), and (68). But the management, otherwise it is not accepted. High institutional support research conducted by (76) but does not support

This study proposes four research hypotheses. From the

that effective audit quality attributes can reduce earnings management.

This research contribution is to use institutional ownership variables as moderating variables. However, the results of this study state that institutional ownership does not moderate audit quality on earnings management, while the influence of information asymmetry on earnings management is influenced by institutional ownership as a moderating variable. So it can be concluded that audit quality can directly affect earnings management without going through institutional ownership intermediaries, whereas information asymmetry cannot be directly related to earnings management.

Like most similar studies, this study is subject to inevitable limitations. Although this study has attempted to use accurate and up-to-date proxies for earnings management, discretionary accruals are a standard measure of earnings management, these measures are prone to measurement errors and thus the validity of these findings depends on the accuracy of discretionary accruals as the right proxy for earnings management. In addition, the quality of the selection of the right proxy for the information asymmetry variable also makes an important thing other than by using the difference between the selling price and the purchase price of the stock.

This finding has implications for researchers in the development of the audit and accounting professions by increasing auditor independence and competence and solving problems in the Indonesian capital market. In addition, it is time for companies listed on the Indonesia Stock Exchange to disclose audit service fees and non-audit service fees because this can contribute to solving the problem of reducing audit fees.

Finally, the lack of evidence about this potential relationship shows that, just using agency theory cannot solve the problem. Therefore, it is hoped that future research will further explore research questions using alternative theories.

\section{ACKNOWLEDGMENT}

This research work is supported by the Indonesia Endowment Fund for Education of the Ministry of Finance Republic Indonesia (LPDP Indonesia).

\section{REFERENCES}

1. Alzoubi ESS. Audit Quality, Debt Financing, and Earnings Management: Evidence from Jordan. J Int Account, Audit Tax. 2018;30:69-84.

2. Lin J, Hwang MI. Audit Quality, Corporate Governance , and Earnings Management: A Meta-Analysis. Int J Audit. 2010;14:57-77.

3. Arens AA, Elder RJ, Beasley MS. Auditing and Assurance Services: An Integrated Approach [Internet] 14th ed. Prentice Hall; 2012 [cited 2018 Dec 26]. 850 p. Available http://lib.hpu.edu.vn/handle/123456789/22033

4. Messier WF, Glover SM, Prawitt DF. Auditing \& Assurance Services: A Systematic Approach. New York: McGraw-Hill/Irwin; 2008 
5. Liao P, Shih Y, Wu C, Zhang X, Wang Y. Does Corporate Social Performance Pay Back Quickly? A Longitudinal Content Analysis on International Contractors. J Clean Prod. Elsevier B.V.; 2017;

6. Xie B, Davidson WN, DaDalt PJ. Earnings Management and Corporate Governance: The Role of The Board and The Audit Committee. J Corp Financ. 2003;9:295-316.

7. 7. Richardson VJ. Information Asymmetry and Earnings Management: Some Evidence. Rev Quant Financ Account. 2000;15:325-47.

8. Hasan T, Cornett MM, Marcus AJ, Saunders A. Earnings Management, Corporate Governance, and True Financial Performance. 142 [Internet]. 2006; Available from: https://papers.ssrn.com/sol3/papers.cfm?abstract_id=886 142 Managerial Behaviour, Agency Costs y Ownership Structure. J financ econ [Internet]. 1976;3(4):305-60. Available from: http://search.ebscohost.com/login.aspx?direct=true $\& d b=$ buh\&AN $=12243301 \&$ site $=$ ehost-live

10. Habbash M, Alghamdi S. Audit Quality and Earnings Management in Less Developed Economies: The Case of Saudi Arabia. J Manag Gov. Springer US; 2017;21(2):351-73.

11. Velury U. The Association Between Auditor Industry Specialization and Earnings Management. Res Account Regul. 2003;16(C):171-84.

12. Jones M. Creative Accounting, Fraud and International $482 \mathrm{p}$.

13. Libby R, Rennekamp KM, Seybert N. Regulation and The Interdependent Roles of Managers, Auditors, and Directors in Earnings Management and Accounting Choice. Accounting, Organ Soc [Internet]. Elsevier Ltd; 2015;47:25-42. Available from: http://dx.doi.org/10.1016/j.aos.2015.09.003

14. Stolowy H, Breton G. Accounts Manipulation: A Literature Review and Proposed Conceptual Framework. Rev Account Financ. 2004;3(1):5-92.

15. Gul FA, Fung SYK, Jaggi B. Earnings Quality: Some Evidence on The Role of Auditor Tenure and Auditors' Industry Expertise. J Account Econ [Internet]. Elsevier; 2009;47(3):265-87. Available from: http://dx.doi.org/10.1016/j.jacceco.2009.03.001

16. Boediono GS. Kualitas Laba: Studi Pengaruh Mekanisme Corporate Governance dan Dampak Manajemen Laba dengan Menggunakan Analisis Jalur. In: Simposium Nasional Akuntansi VIII. Solo; 2005.

17. Guercio D Del, Hawkins J. The Motivation and Impact of Pension Fund Activism. $J$ financ econ. 1999;52(3):293-340.

18. Hartzell JC, Starks LT. Institutional Investors and Executive Compensation. $\mathrm{J}$ Finance [Internet]. 2003;58(6):2351-74. Available from: http://onlinelibrary.wiley.com/doi/10.1046/j.15406261.2003.00608.x/full

19. Charitou A, Lambertides N, Trigeorgis L. Earnings Behaviour of Financially Distressed Firms: The Role of Institutional Ownership. Abacus. 2007;43(3):271-96.

20. Fan JPH, Wong TJ. Corporate Ownership Structure and The Informativeness of Accounting Earnings in East Asia. 2002;33:401-25.

21. Donnelly R, Lynch C. The Ownership Structure of UK Firms and The Informativeness of Accounting Earnings. https://papers.ssrn.com/sol3/papers.cfm?abstract_id=886

9. Jensen MC, Meckling W. Theory of the Firm: Accounting Scandals. Wiley. Wiley, Canada; 2011. 481Account Bus Res. 2002;32(4):245-57.

22. Firth M, Fung PMY, Rui OM. Ownership, Two-Tier Board Structure, and The Informativeness of Earnings Evidence from China. J Account Public Policy. 2007;26(4):463-96.

23. Wedari L. Analisis Pengaruh Proporsi Dewan Komisaris dan Keberadaan Komite Audit terhadap Aktivitas Manajemen Laba. In: Simposium Nasional Akuntansi VII [Internet]. 2004. Available from: http://scholar.google.co.id/scholar?start=10\&q=pengaruh $\& \mathrm{hl}=\mathrm{id} \&$ as $\_\mathrm{sdt}=0,5 \# 6$

24. Sriwedari T. Mekanisme Good Corporate Governance, Manajemen Laba dan Kinerja Keuangan Perusahaan Manufaktur di Bursa Efek Indonesia. J Mediasi 2012;4(1):78-88

25. Belkaoui AR. Accounting Theory. 4th ed. Thomson Learning; 2000.

26. Widyaningdyah AU. Analisis Faktor-faktor yang Berpengaruh terhadap Earnings Management pada Perusahaan Go Public di Indonesia. J Ekon Akunt. 2001;3(2):89-101.

27. DeAngelo LE. Auditor Size and Audit Quality. J Account Econ. 1981;3(July):183-99.

28. Becker CL, Defond ML, Jiambalvo J, Subramanyam KR The effect of audit quality on earnings management Contemp Account Res. 1998;15(1):1-24.

29. Fidyati N. Pengaruh Mekanisme Corporate Governance terhadap Earnings Management pada Perusahaan Seasoned Equity Offering. J Ekon Manaj Akunt. 2004:2(1):55-67.

30. Beneish MD. Detecting GAAP Violations: Implications for Assessing Earnings Management Among Firms with Extreme Financial Performance. J Account Public Policy. 1997;16:271-309.

31. DeFond ML, Wong TJ, Li S. The Impact of Improved Auditor Independence on Audit Market Concentration in China. J Account Econ. 1999;28(3):269-305.

32. Lai LHY. Are Independent Directors Effective in Lowering Earnings Management in China? Texas A \&M University; 2005. 1-95 p.

33. Ningsaptiti R. Analisis Pengaruh Ukuran Perusahaan Dan Mekanisme Corporate Governance Terhadap Manajemen Laba. In: Skripsi S1. Semarang: Tidak Dipublikasikan; 2010.

34. Chtourou S, Bedard J, Courteau L. Corporate Governance and Earnings Management. 2001; Available from: http://papers.ssrn.com/

35. Siregar SVNP, Utama S. Pengaruh Struktur Kepemilikan, Ukuran Perusahaan, dan Praktek Corporate Governance terhadap Pengelolaan Laba (Earnings Management). In: Simposium Nasional Akuntansi VIII Solo; 2005. p. 475-90.

36. Nasution M, Setiawan D. Pengaruh Corporate Governance terhadap Manajemen Laba di Industri Perbankan Indonesia. In: Simposium Nasional Akuntansi VIII. Makassar; 2007. p. 1-26.

37. Watts RL, Zimmerman JL. Positive Accounting Theory: A Ten Year Perspective. Account Rev. 1990;65(1):13156.

38. Schiff M, Lewin AY. The Impact of People on Budgets Account Rev. 1970;45(2):259-68.

39. Rusmin R. Auditor Quality and Earnings Management Singaporean Evidence. Manag Audit J. 2010;25(7):618 38.

40. DeAngelo LE. Auditor Independence, 'Low Balling', and Disclosure Regulation. J Account Econ. 1981;3(January):113-27. 
41. Lai KW. Does Audit Quality Matter More for Firms with High Investment Opportunities? J Account Public Policy [Internet]. Elsevier Inc.; 2009;28(1):33-50. Available from: http://dx.doi.org/10.1016/j.jaccpubpol.2008.11.002

42. Bliss MA, Gul FA, Majid A. Do Political Connections Affect The Role of Independent Audit Committees and CEO Duality? Some Evidence From Malaysian Audit Pricing. J Contemp Account Econ [Internet]. Elsevier Ltd; 2011;7(2):82-98. Available from: http://dx.doi.org/10.1016/j.jcae.2011.10.002

43. Chi H-Y, Weng T. Managerial Legal Liability and Big 4 Auditor Choice. J Bus Res [Internet]. Elsevier Inc.; 2013; Available

from: http://dx.doi.org/10.1016/j.jbusres.2013.12.003

44. Du J, Dai Y. Ultimate Corporate Ownership Structures and Capital Structures: Evidence from East Asian Economies. Corp Gov an Int Rev. 2005;13(1):60-71.

45. Faccio M, Lang LH., Young L. Dividends and Expropriation. Am Econ Rev. 2001;91:54-78.

46. Song J, Wang R, Cavusgil ST. State Ownership and Market Orientation in China's Public Firms : An Agency Theory Perspective. Int Bus Rev. 2015;24:690-2.

47. Midiastuty PP, Machfoedz M. Analisis Hubungan Mekanisme Corporate Governance dan Indikasi Manajemen Laba. In: Simposium Nasional Akuntansi VI. Surabaya; 2003. p. 176-99.

48. 48. Singawinata IP. The Future of The Indonesian Mining Industry: Recommendations to Policy Makers. Ritsumeikan J Asia Pacific Stud. 2007;3:99-113.

49. Kothari SP. Capital Markets Research in Accounting. J Account Econ [Internet]. 2001;31:105-231. Available from:

http://www.sciencedirect.com/science/article/pii/S01654 10101000301

50. Dechow PM, Sloan RG, Sweeney AP. Detecting Earnings Management. Account Rev [Internet]. 1995;70(2):193-225. Available from: http://www.jstor.org/stable/248303\%5Cnhttp://www.jsto r.org/stable/pdfplus/248303.pdf?acceptTC=true

51. Guay WR, Kothari SP, Watts RL. A Market-Based Evaluation of Discretionary Accrual Models Published. J Account Res. 1996;34:83-105.

52. Kasznik R. On the Association between Voluntary Disclosure and Earnings Management. J Account Res. 1999;37(1):57-81.

53. Bartov E. The Timing of Asset Sales and Earnings Manipulation. Account Rev. 1993;68(4):840-55.

54. Jones JJ. Earnings Management During Import Relief Investigations. J Account Res [Internet]. 1991;29(2):193-228. Available from: http://www.jstor.org/stable/2491047?origin=crossref

55. DeFond ML, Jiambalvo J. Factors Related to Auditor-Client Disagreements over Income-Increasing Accounting Methods. Contemp Account Res. 1993;9(2):415-31.

56. Butler M, Leone AJ, Willenborg M. An Empirical Analysis of Auditor Reporting and its Association With Abnormal Accruals. J Account Econ. 2004;37(2):13965.

57. Siallagan H, Machfoedz M. Mekanisme Corporate Governance, Kualitas Laba dan Nilai Perusahaan. In: Simposium Nasional Akuntansi IX. Padang; 2006. p. 123.

58. Bessembinder H, Venkataraman K. Encyclopedia of Quantitative Finance [Internet]. 2010. Available from: http://people.smu.edu/kumar/pubs/bid-ask-spreadsmeasuring-trade-execution-costs-in-financial-markets/
59. Weston JF, Copeland T. Managerial Finance. 9th ed. Texas: The Dryden Press. Fort Worth. Texas.; 1992.

60. Klein A. Audit Committee, Board of Director Characteristics, and Earnings Management. J Account Econ. 2002;33:375-400.

61. Lin JW, Li JF, Yang JS. The Effect of Audit Committee Performance on Earnings Quality. Manag Audit J [Internet]. 2006;21(9):921-33. Available from: http://www.emeraldinsight.com/doi/10.1108/026869006 10705019

62. Gujarati DN. Basic Econometrics, 4th edition. 4th ed. Boston: Mc Graw Hill; 2003.

63. Sulistyanto S. Manajemen Laba: Teori dan Model Empiris. Jakarta: PT. Gramedia Widiasarana Indonesia; 2008.

64. Healy PM, Palepu KG. Information Asymmetry, Corporate Disclosure and the Capital Markets: A Review of the Empirical Disclosure Literature. J Account Econ [Internet]. 2001;31:405-40. Available from: http://papers.ssrn.com/sol3/papers.cfm?abstract_id=2585 14

65. Wiryadi A, Sebrina N. Pengaruh Asimetri Informasi, Kualitas audit, dan Struktur Kepemilikan terhadap Manajemen Laba. J Wahana Ris Akunt. 2013;1(2):15580.

66. Kraft A, Lee BS, Lopatta K. Management Earnings Forecasts, Insider Trading, and Information Asymmetry. J Corp Financ [Internet]. Elsevier B.V.; 2014;26:96-123. Available http://dx.doi.org/10.1016/j.jcorpfin.2014.03.002

67. Dai Y, Kong D, Wang L. Information Asymmetry, Mutual Funds and Earnings Management: Evidence from China. China J Account Res [Internet]. Sun Yat-sen University; 2013;6(3):187-209. Available from: http://dx.doi.org/10.1016/j.cjar.2013.03.001

68. Lin TJ, Chen YP, Tsai HF. The Relationship Among Information Asymmetry, Dividend Policy and Ownership Structure. Financ Res Lett [Internet]. Elsevier Inc.; 2016;20:1-12. Available from: http://dx.doi.org/10.1016/j.frl.2016.06.008

69. Wang LH. Accounting Quality and Information Asymmetry of Foreign Direct Investment Firms. Res Int Bus Financ. Elsevier B.V.; 2017;42:950-8.

70. Chang CC, Kao LH, Chen HY. How Does Real Earnings Management Affect The Value of Cash Holdings? Comparisons Between Information and Agency Perspectives. Pacific Basin Financ J. Elsevier B.V; 2018;51(2017):47-64.

71. Hope OK, Wang J. Management Deception, Big-bath Accounting, and Information Asymmetry: Evidence from Linguistic Analysis. Accounting, Organ Soc [Internet] Elsevier; 2018;(April 2017). Available from: http://dx.doi.org/10.1016/j.aos.2018.02.004

72. Zgarni I, Hlioui K, Zehri F. Effective Audit Committee, Audit Quality and Earnings Management. J Account Emerg Econ [Internet]. 2016;6(2):138-55. Available from:

http://www.emeraldinsight.com/doi/10.1108/JAEE-092013-0048

73. Barghathi Y, Collison D, Crawford L. Earnings Management and Audit Quality: Stakeholders' Perceptions. J Manag Gov [Internet]. Springer US; 2017; Available http://link.springer.com/10.1007/s10997-017-9396-2

74. Muttakin MB, Khan A, Mihret DG. Business Group Affiliation, Earnings Management and Audit Quality: Evidence from Bangladesh. Manag Audit J. 2017;32(4/5):427-44. 
International conference on Recents Advancements in Engineering and Technology (ICRAET-18) |15th and 16th March 2019|Siddhartha Institute of Technology \& Sciences, Telangana, India.

75. Alhadab M, Clacher I. The Impact of Audit Quality on Real and Accrual Earnings Management Around IPOs. Br Account Rev. Elsevier; 2018;50(October 2017):44261 .

76. Rusmin R, Astami EW, Hartadi B. The Impact of Surplus Free Cash Flow and Audit Quality on Earnings Management: The Case of Growth Triangle Countries. Asian Rev Account. 2014;22(3):217-32.

\section{AUTHORS PROFILE}

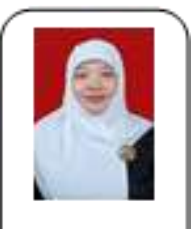

Metta Kusumaningtyas, Lecturer in the Accounting Study Program, STIE Bank BPD Jawa Tengah, Semarang, Central Java, Indonesia. Graduated in 2001 with a Bachelor of Economics in Accounting and a Masters in Accounting in 2011, from the Faculty of Economics and Business, Diponegoro University, Semarang, Central Java, Indonesia. Currently, precisely since 2017 is continuing studies in the Doctoral Program in Economics, Accounting Concentration, Faculty of Economics and Business, Diponegoro University, Semarang, Central Java, Indonesia. Research conducted so far has focused on the field of Financial Accounting. The research conducted has been published in several national journals. In addition is also active as a board of the Indonesian Institute of Accountants in the Central Java Region.

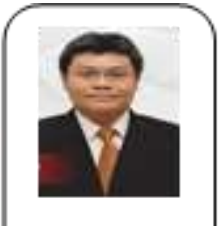

Anis Chariri, Lecturer in Accounting Study Program, Faculty of Economics and Business, Diponegoro University, Semarang, Central Java, Indonesia. Graduated in 1991 with a Bachelor of Economics in Accounting from the Accounting Study Program, Faculty of Economics and Business, Gadjah Mada University, Yogyakarta, Indonesia. Completed a Master's degree at The University of New South Wales, Australia, with a M.Com degree, in 1996. He holds a PhD, from University Of Wollongong, Australia, in 2007. Currently, precisely since May 2019, obtained the highest academic degree achievement as a Professor in Forensic Accounting. Research conducted so far has focused on the field of Forensic Accounting, several published in well-indexed national journals and scopus indexed international journals. The work of the book produced includes Accounting Theory; Intellectual Capital and Corporate Financial Performance: An Analysis with a Partial Least Squares (PLS) Approach; Philosophy Platform and Qualitative Research Methods.

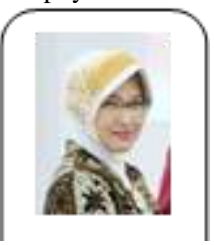

Etna Nur Afri Yuyetta, Lecturer in Accounting Study Program, Faculty of Economics and Business, Diponegoro University, Semarang, Central Java, Indonesia. Graduated in 1996 with a Bachelor of Economics in Accounting from the Accounting Study Program, Faculty of Economics and Business, Gadjah Mada University, Yogyakarta, Indonesia. Completed Master's degree in 2001 and Doctoral in 2008 from the Faculty of Economics and Business, Gadjah Mada University, Yogyakarta, Indonesia. The research carried out so far has focused on the field of Financial Accounting, specifically the Capital Market. The results of several studies were published in nationally indexed national journals and scopus indexed international journals. 